\title{
Gangguan siklus menstruasi kaitannya dengan asupan zat gizi pada remaja vegetarian
}

\author{
Yulia Wahyuni*, Ratna Dewi
}

\begin{abstract}
Background : Adolescence is a period that is still experiencing growth, especially the reproductive system with menstruation is supported adequate nutrients.

Objective : The aim of this study was to determined the association of the sufficient of protein, vitamin B12, vitamin C, iron intake, nutritional status with cycle mestruasi on vegetarian adolescent at IVS Jakarta 2017.

Method : This design research was observation analytic with cross sectional approach. Sampling technique were used total sampling. The technique of data collection were used menstrual cycle questionnaire, Semi Quantitatif Food Frequency, food model, nutrisurvey, BMI for age.

Results : There was 35,71 \% respondents have an oligomenorrhea. Food intake (protein, vitamin B12, vitamin C, iron) were inadequate, while vitamin $C$ was intake adequate. Based on statistical analysis of Spearman Rank test, There were significant relation between sufficient intake of protein $(p=0,001)$, sufficient intake of vitamin $C(p=0,003)$ sufficient intake of iron $(p=$ $0,001)$ with menstrual cycle. There was no significant relationship between vitamin B12 intake $(P=0.34)$ nutritional status $(P$ $=0.54$ ) with menstrual cycle.

Conclusion : food intake (protein, iron, vitamin C) associated with the menstrual cycle. vitamin B12 intake and nutritional status not associatied with the menstrual cycle.
\end{abstract}

Keywords : Nutrition, menstruation, vegetarian, nutritional status, IVS

\begin{abstract}
ABSTRAK
Latar Belakang : Remaja sebagai kelompok usia yang masih mengalami pertumbuhan khususnya sistem reproduksi dengan mengalami menstruasi sangat perlu didukung zat gizi yang memadai.

Tujuan : mengetahui hubungan asupan protein, vitamin B12, vitamin C, zat besi, status gizi dengan siklus mestruasi pada remaja vegetarian di IVS Jakarta tahun 2017.

Metode : Desain penelitian adalah observasi analitik dengan pendekatan cross sectional. Teknik Pengambilan sampling yang digunakan total sampling. Pengumpulan data melalui kuisioner siklus mentruasi, Semi Quantitatif Food Frequency, food model, nutrisurvey dan IMT/U.

Hasil : Remaja yang mengalami oligomenorrhea sebanyak 35,71\%. Asupan protein, vitamin B12 dan zat besi kurang dari kebutuhan tubuh sedangkan asupan vitamin C lebih dari kebutuhan tubuh. Hasil uji Rank Spearman menunjukkkan ada hubungan bermakna antara asupan protein $(p=0,001)$, vitamin $C(p=0,003)$ zat besi $(p=0,001)$ dengan siklus menstruasi. Tidak ada hubungan bermakna antara asupan vitamin $B 12(p=0,34)$ status gizi $(p=0.54)$ dengan siklus menstruasi.

Simpulan : asupan protein, zat besi, vitamin $C$ berhubungan dengan siklus menstruasi. Namun berbeda dengan asupan vitamin B12 dan status gizi yang tidak berhubungan dengan siklus menstruasi.
\end{abstract}

Kata kunci : Zat gizi, menstruasi, vegetarian, status gizi

\section{PENDAHULUAN}

Remaja sebagai masa peralihan antara masa anak-anak dan dewasa dengan usia antara 12-24 tahun. ${ }^{1}$ Kelompok remaja tersebut dikategorikan menjadi tiga kelompok yaitu remaja awal (12-15 tahun), remaja pertengahan (15-18 tahun) dan remaja akhir (19-21 tahun). Jumlah kelompok remaja di Indonesia menurut sensus penduduk 2010 adalah 43,5 juta atau $18 \%$ dari jumlah penduduk dan di dunia

Fakultas Ilmu Kesehatan, Universitas Esa Unggul. Jl. Arjuna Utara No.9, RT.1/RW.2, Duri Kepa, Kb. Jeruk, Kota Jakarta Barat, Daerah Khusus Ibukota Jakarta 11510

*Korespondensi : email : yulia.wahyuni@esaunggul.ac.id diperkirakan 1,2 milyar remaja. ${ }^{1}$ Pada masa remaja terjadi peningkatan kebutuhan gizi dikarenakan pada masa remaja laju pertumbuhan meningkat. ${ }^{2}$ Keadaan ini menjadi tantangan bagi remaja vegetarian.

Vegetarian menjadi suatu gaya hidup seseorang baik karena alasan keyakinan maupun karena kesehatan. Vegetarian sebagai upaya preventif terjadinya penyakit tidak menular. ${ }^{3}$ Namun demikian, kelompok vegetarian cenderung mengalami defisiensi zat gizi. ${ }^{4}$ Jumlah vegetarian di negara Italia terdiri dari $12 \%$ dari populasi. Jumlah penduduk vegetarian di Inggris sebanyak $4 \%$ dari populasi sedangkan di Amerika sebanyak 3\% dari popolasi. ${ }^{3}$ Menurut hasil survei tahun 2014 menunjukkan anggota IVS (Indonesian Vegetarian Society) sebanyak 80 ribu anggota yang tersebar disetiap propinsi di Indonesia. 
Jumlah vegetarian di Jakarta sebanyak 800 anggota dan remaja vegetarian sebanyak 3\%. Jumlah rumah makan yang menyediakan menu vegetarian di Jakarta sebanyak 77 rumah makan. ${ }^{8}$

Remaja vegetarian cenderung mengalami defisiensi beberapa zat gizi seperti protein, zat besi $(\mathrm{Fe})$, Vitamin B12. Protein nabati merupakan protein dengan nilai biologis rendah karena tidak mengandung semua asam amino esensial yang dibutuhkan untuk proses fisiologis tubuh. ${ }^{9}$ Asupan zat besi vegetarian adalah zat besi nonheme yang terdapat dalam bahan makanan nabati yang kandungan zat besi rendah dan tingkat penyerapannya sangat rendah. Absorpsi besi yang efektif dan efisien memerlukan suasana asam dan adanya reduktor, seperti vitamin C. Absorpsi besi dalam bentuk nonheme dapat meningkat empat kali lipat dengan adanya vitamin C. Oleh karena itu, kekurangan vitamin $\mathrm{C}$ dapat menghambat proses absorpsi besi. Vitamin $\mathrm{C}$ dapat menghambat pembentukan hemosiderin yang diimobilisasi untuk membebaskan besi jika diperlukan. Vitamin $\mathrm{C}$ juga memiliki peran dalam pemindahan besi dari transferin di dalam plasma ke feritin hati. ${ }^{10}$ Vitamin B12 yang berasal dari bahan pangan nabati jumlah dan tingkat penyerapannya juga sangat rendah.

Hal ini sebagai risiko potensial defisiensi zat gizi bagi kelompok remaja putri yang mengalami menstruasi setiap bulan. ${ }^{5}$ Asupan zat gizi yang kurang dari kebutuhan tubuh dapat menyebabkan siklus menstruasi tidak teratur. ${ }^{6}$ Siklus menstruasi dihitung berdasarkan lamanya empat fase pada satu siklus menstruasi. Fase-fase siklus menstruasi tersebut adalah fase menstrual, fase preovulatori, ovulasi dan fase pasca ovulatori. Satu siklus menstruasi terjadi selama 25 hingga 32 hari. $^{7}$ Remaja vegetarian yang defisiensi protein, vitamin $\mathrm{C}$ dan zat besi berkaitan dengan fase preovulatori sedangkan defisiensi vitamin B12 berkaitan dengan fase ovulasi. ${ }^{18}$ Selain itu kelebihan dan kekurangan gizi secara umum berdampak pada penurunan fungsi hipotalamus memberikan ransangan impuls ke Follicle Stimulating Hormone (FSH) dan Luteinizing Hormone (LH). Kedua hormon ini berperan penting dalam mengatur siklus menstruasi. Hasil survei pendahuluan menunjukkan bahwa beberapa remaja vegetarian memiliki siklus mentruasi serta pola makan yang tidak teratur. Tujuan penelitian ini untuk mengetahui hubungan asupan protein, vitamin B12, dan vitamin $\mathrm{C}$, status gizi dengan siklus mestruasi pada remaja vegetarian.

\section{BAHAN DAN METODE}

Penelitian ini menggunakan desain observasi analitik dengan pendekatan cross sectional yakni semua data yang dibutuhkan dikumpulkan dalam satu waktu. ${ }^{13}$ Lokasi penelitian di Jakarta yang terbagi atas Jakarta Barat, Jakarta Timur, Jakarta Selatan dan Jakarta Utara sesuai dengan persebaran responden. Responden dalam penelitian ini adalah remaja vegetarian yang bergabung pada kelompok IVS Jakarta. Penelitian ini dilakukan selama 3 bulan yakni dari bulan Juli - September 2017.

Data primer yang diambil dalam penelitian ini adalah data asupan zat gizi (protein, zat besi, vitamin B12, vitamin C), status gizi dan data siklus menstruasi. Asupan zat gizi (protein, zat besi, vitamin B12, vitamin C) dan status gizi merupakan variabel independen sedangkan variabel dependen adalah siklus menstruasi. Data asupan protein, zat besi, vitamin B12 dan vitamin C diperoleh dengan Semi Quantitatif Food Frequency dengan alat bantu food model. Data status gizi ditentukan berdasarkan nilai indeks masa tubuh menurut umur. Data berat badan menggunakan timbangan injak tanita dengan kapasitas $136 \mathrm{~kg}$ dan keakuratan $0,1 \mathrm{~kg}$. Pengukuran tinggi badan menggunakan microtoise dengan kapasitas 200 $\mathrm{cm}$ dan keakuratan $0,1 \mathrm{~cm}$. Data asupan zat gizi diolah dengan menggunakan nutrisurvey. Data siklus menstruasi remaja menggunakan kuisioner siklus menstruasi. Gangguan siklus menstruasi terdiri dari oligomenorrhea dan polymenorrhea. Pengolahan data siklus menstruasi dengan menggunakan skor. Siklus menstruasi teratur $(25-32$ hari) diberi skor 1. Gangguan siklus menstruasi diberi skor 0. Gangguan siklus menstruasi ada 2 yaitu oligomenorrhea $(>32$ hari) dan polymenorrhea ( $<25$ hari). Pengambilan sampel dengan teknik total sampling dan memenuhi kriteria inklusi : pertama, responden memiliki siklus haid yang tetap selama 6 bulan terakhir. Kedua, responden mengikuti penelitian sampai akhir. Analisis data menggunakan program komputer. Uji statistik yang digunakan Uji Rank Spearman yang digunakan untuk mengetahui hubungan antara variabel independen yakni asupan zat gizi (protein, zat besi, vitamin B12, vitamin C ) dan variabel dependen yakni siklus menstruasi.

\section{HASIL}

\section{Karakteristik Responden}

Responden dalam penelitian ini adalah remaja vegetarian lacto ovo sebanyak 84 orang. Rentang umur responden dalam penelitian ini berumur 12-24 tahun. Tiga kategori usia responden yakni remaja awal (12-15 tahun), remaja pertengahan (16-18 tahun), dan remaja akhir (19-24 tahun). Remaja awal sebanyak 28 orang $(33,33 \%)$, remaja pertengahan sebanyak 33 orang $(39,29 \%)$ dan remaja akhir sebanyak 23 orang $(27,38 \%)$. 
Tabel 1. Distribusi Responden Berdasarkan Asupan Protein, Vitamin B12, Zat Besi dan Vitamin C

\begin{tabular}{llll}
\hline Variabel & Mean \pm SD & Minimal - Maksimal & SE \\
\hline Asupan Protein (g) & $46,04 \pm 6,92$ & $25,1-60,9$ & 0,75 \\
Asupan Vitamin B12 (mcg) & $1,59 \pm 0,28$ & $1-2,1$ & 0,03 \\
Asupan zat besi (mg) & $18,05 \pm 28,54$ & $12,8-22,4$ & 3,1 \\
Asupan Vitamin C (mg) & $82,5 \pm 1,34$ & $67,3-97,8$ & 0,1 \\
\hline
\end{tabular}

Asupan protein, vitamin B12, vitamin C, zat besi menggunakan Semi Quantitatif Food Frequency. Berdasarkan Tabel 1 dapat diketahui bahwa dari 84 responden rata-rata asupan protein sebesar 46,04 $\mathrm{g}$ dengan standar deviasi 9,11 g. Asupan protein tersebut menunjukkan bahwa sebagian besar asupan protein remaja vegetarian lacto ovo IVS Jakarta kurang dari kebutuhan tubuh. Rata-rata asupan vitamin B12 sebesar 1,59 mcg dengan standar deviasi $0,28 \mathrm{mcg}$ yang artinya sebagian besar asupan vitamin B12 remaja vegetarian lacto ovo Jakarta kurang dari kebutuhan tubuh. Asupan zat besi responden rata-rata $18,05 \mathrm{mg}$ dengan standar deviasi 28,54 mg. Hal ini menunjukkan bahwa sebagian besar asupan zat besi remaja vegetarian lakto ovo IVS Jakarta kurang dari kebutuhan tubuh. Rata-rata asupan vitamin $\mathrm{C}$ responden 82,5 $\mathrm{mg}$ dengan standar deviasi 1,34 $\mathrm{mg}$ yang artinya asupan vitamin $\mathrm{C}$ remaja vegetarian lakto ovo IVS Jakarta lebih dari kebutuhan tubuh.

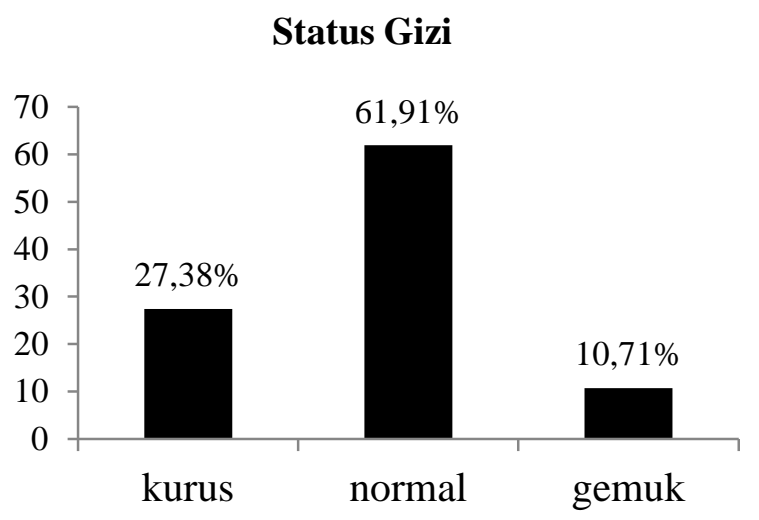

Gambar 1. Distribusi Responden Berdasarkan Status Gizi

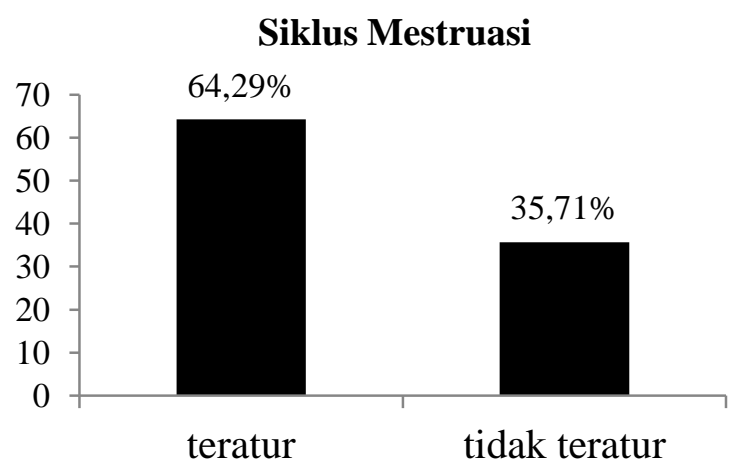

Gambar 2. Distribusi Responden Berdasarkan Siklus Menstruasi
Gambar 1 menunjukkan bahwa dari 84 remaja vegetarian lakto ovo yang tergabung dalam IVS Jakarta sebanyak 32 orang $(38,09 \%)$ yang mengalami masalah gizi yakni sebanyak 9 orang $(10,71 \%)$ tergolong gemuk dan 23 orang $(27,38 \%)$ tergolong kurus.

Gambar 2 memperlihatkan bahwa sebanyak 30 orang $(35,71 \%)$ reponden yang mengalami gangguan siklus menstruasi (siklus menstruasi tidak teratur). Siklus menstruasi yang tidak teratur tersebut masuk pada kategori oligomenorrhea (> 32 hari).

\section{Analisis Bivariat}

Analisis bivariat digunakan untuk mengetahui hubungan asupan zat gizi (protein, vitamin B12, vitamin $\mathrm{C}$, zat besi) dan status gizi dengan siklus menstruasi remaja vegetarian lakto ovo IVS Jakarta. Analisis bivariat yang digunakan dalam penelitian ini menggunakan uji korelasi Rank Spearman.

Tabel 2. Hubungan Asupan Zat Gizi (Protein, Vitamin B12, Vitamin C, Zat Besi) dan Status Gizi Terhadap Siklus Menstruasi

\begin{tabular}{ccc}
\hline Variabel & $\boldsymbol{r}$ & $\boldsymbol{p}$ \\
\hline Protein & 0,84 & 0,001 \\
Vitamin B12 & 0,23 & 0,34 \\
Vitamin C & 0,52 & 0,003 \\
Zat besi & 0,67 & 0,001 \\
Status gizi & 0,60 & 0,54 \\
\hline
\end{tabular}

Berdasarkan Tabel 2 dapat diketahui bahwa ada hubungan yang signifikan antara asupan protein, vitamin $\mathrm{C}$ dan zat besi terhadap siklus menstruasi remaja vegetarian lakto ovo. Nilai korelasi (r) asupan protein dan zat besi adalah $\mathrm{r}=0,84$ dan 0,67 yang menunjukkan bahwa kekuatan hubungan antara asupan zat besi, protein terhadap siklus menstruasi remaja vegetarian lakto ovo kuat dan sangat kuat. Sedangkan nilai korelasi asupan vitamin $C, r=0,52$ yang artinya kekuatan hubungan asupan vitamin $\mathrm{C}$ terhadap siklus menstruasi remaja vegetarian lakto ovo sedang. Asupan protein, zat besi dan vitamin $\mathrm{C}$ terhadap siklus menstruasi memiliki korelasi positif yang artinya semakin baik asupannya makan siklus menstruasinya semakin teratur. Namun, tidak ada hubungan asupan vitamin B 12 dan status gizi dengan siklus menstruasi remaja vegetarian lacto ovo. 


\section{PEMBAHASAN}

Pada masa remaja terjadi peningkatan kebutuhan gizi dikarenakan pada masa remaja laju pertumbuhan meningkat. ${ }^{2}$ Hasil penelitian menujukkan bahwa dari 84 remaja putri vegetarian lacto ovo sebanyak sebanyak 28 orang $(33,33 \%)$ sebagai remaja awal, 33orang $(39,29 \%)$ sebagai remaja pertengahan dan remaja akhir sebanyak 23 orang $(27,38 \%)$. Masa remaja merupakan masa dimana terjadi pertumbuhan fisik dan psikis dan juga pertumbuhan sosial yang membantu menyempurnakan pola pikir, sikap dan perilaku. ${ }^{14}$ Dengan demikian masa remaja sudah mampu mengambil keputusan sendiri dalam bertingkah laku seperti dalam berkomitmen untuk mengikuti vegetarian lacto ovo.

Remaja vegetarian lacto ovo merupakan remaja yang tidak mengonsumsi daging dan namun mengonsumsi susu dan telur. ${ }^{15}$ Remaja vegetarian lacto ovo tidak mendapat zat gizi yang bersumber dari hewani. Keadaan ini bertentangan dengan kebutuhan gizi remaja yang mendukung pertumbuhan sistem tubuh termasuk sistem reproduksi. ${ }^{14}$ Kematangan organ reproduksi pada remaja putri ditandai dengan menstruasi. ${ }^{16}$ Hal ini sesuai dengan hasil penelitian pada remaja vegetarian lacto ovo mengalami gangguan siklus menstruasi yakni oligomenorrhea sebanyak $35,71 \%$. Siklus menstruasi yang teratur menjadi salah satu indikator tingkat fertilitas. ${ }^{17}$

\section{Hubungan Asupan Zat Gizi (Protein, Vitamin C, Vitamin B12 dan Zat Besi) dengan Siklus Menstruasi Remaja Vegetarian Lacto Ovo di IVS Jakarta}

Asupan protein yang adekuat sangat penting untuk mengatur integritas, fungsi, dan kesehatan manusia dengan menyediakan asam amino sebagai prekursor molekul esensial yang merupakan komponen dari semua sel dalam tubuh. ${ }^{10}$ Hasil analisis nutrisurvey menunjukkan asupan protein rendah dari kebutuhan tubuh. Bahan makanan sumber protein hanya berasal dari tahu dan tempe dan juga kacang-kacangan. Sebagian besar remaja vegetarian lacto ovo jarang mengonsumsi susu dan telur. Hasil uji korelasi Rank Spearman menunjukkan bahwa ada hubungan yang signifikan asupan protein responden dengan siklus menstruasi. Kekuatan hubungannya sangat kuat dengan korelasi positif yang artinya semakin tinggi asupan protein (sesuai dengan kebutuhan tubuh) maka siklus menstruasi semakin teratur begitupun sebaliknya.

Pemenuhan kebutuhan protein yang kurang dari kebutuhan tubuh akan mempengaruhi kadar estrogen sehingga kadar FSH tidak mencapai puncak. Dampak dari pertumbuhan follikel terhenti adalah tidak terjadi ovulasi. Keadaan ini berpengaruh pada perpanjangan siklus menstruasi (oligomenorrhea).$^{18}$ Hasil penelitian ini sejalan dengan penelitian lain yang menunjukkan bahwa asupan makan tinggi kalori (karbohidrat, lemak dan protein) terjadi pada fase folikuler sehingga kadar FSH mencapai puncaknya. ${ }^{19}$ Pemenuhan kebutuhan asupan protein dapat membantu memaksimalkan fase folikuler sehingga siklus mentruasinya normal.

Vitamin B12 merupakan salah satu zat gizi mikro yang perperan dalam sintesis hemoglobin pada fase ovulasi. ${ }^{9}$ Hasil analisis nutrisurvey menunjukkan bahwa asupan vitamin B12 remaja vegetarian lacto ovo kurang dari kebutuhan tubuh. Berdasarkan hasil uji Rank Spearman menunjukkan bahwa tidak ada hubungan yang signifikan antara asupan vitamin B12 dengan siklus menstruasi. Pemenuhan asupan vitamin B12 tidak berhubungan dengan siklus menstruasi disebabkan oleh kegunaan vitamin B12 yang tidak lansung berkaitan aktifitas otak dan kerja hormon FSH namun lebih kepada sintesis hemoglobin yang berperan pada fase ovulasi. ${ }^{9}$ Hasil penelitian ini tidak sejalan dengan penelitian lain yang menunjukkan bahwa pemenuhan asupan zat gizi makro dan mikro berpengaruh terhadap siklus menstruasi remaja atlet. Perbedaan ini dikarenakan sumber asupan pada kedua penelitian tersebut.

Asupan zat besi vegetarian lacto ovo sebagai zat besi nonheme yang terdapat dalam bahan makanan nabati yang kandungan zat besi rendah dan tingkat penyerapannya sangat rendah. Absorpsi besi yang efektif dan efisien memerlukan suasana asam dan adanya reduktor, seperti vitamin C. Hasil analisis nutrisurvey menunjukkan bahwa asupan zat besi dari remaja vegetarian lacto ovo kurang dari kebutuhan tubuh sedangkan asupan vitamin $\mathrm{C}$ sesuai dengan kebutuhan tubuh. Beberapa bahan makanan sumber zat besi yang sering dikonsumsi oleh remaja vegetarian lacto ovo adalah bayam, kedelai, alpukat. Hasil uji analisis bivariat menunjukkkan ada hubungan yang signifikan antara asupan zat besi, vitamin $\mathrm{C}$ dengan siklus menstruasi dengan korelasi yang positif. Hal ini menunjukkan semakin tinggi asupan zat besi dan vitamin C (sesuai dengan kebutuhan tubuh) maka siklus menstruasinya semakin teratur, begitupun sebaliknya.

Status besi yang rendah dalam tubuh berdampak pada kadar hemoglobin menurun di bawah batas normal. Peranan dari hemoglobin adalah mengantar oksigen dalam tubuh termasuk ke otak. Siklus menstruasi dikendalikan oleh sistem hormon dan dibantu oleh kelenjar hipofisis pada otak. Apabila kinerja otak berkurang karena jumlah oksigen yang diterima tidak optimum maka akan mempengaruhi kerja hipotalamus. Hipotalamus yang terganggu akan berdampak pula pada kerja hormon estrogen dan progesteron menjadi terhambat. ${ }^{20}$ Sehingga biasanya 
siklus menstruasi tersebut tidak teratur dan panjang (oligomenorrhea). ${ }^{18}$ Hasil penelitian ini sejalan dengan penelitian lain yang menunjukkan bahwa ada hubungan yang signifikan antara asupan zat besi dengan siklus menstruasi. Status besi responden stabil pada fase luteal dan terendah pada fase menstruasi. ${ }^{21}$

\section{Hubungan Status Gizi dengan Siklus Menstruasi Remaja Vegetarian Lacto Ovo di IVS Jakarta}

Faktor yang berpengaruh terhadap siklus menstruasi adalah hormonal, status gizi, stress, usia dan penyakit metabolik seperti penyakit diabetes mellitus. ${ }^{22}$ Hasil penelitian lain menyebutkan bahwa status gizi vegetarian lacto ovo normal dibandingkan dengan vegan. Hasil penelitian tersebut sejalan dengan hasil penelitian ini yakni sebesar 61,91\% remaja vegetarian lacto ovo status gizi normal. Namun meskipun didominasi oleh status gizi normal, sebanyak 32 orang $(38,09 \%)$ yang mengalami masalah gizi yakni sebanyak 9 orang $(10,71 \%)$ yang tergolong gemuk dan 23 orang $(27,38 \%)$ yang tergolong kurus.

Suatu hasil penelitian menunjukkan bahwa responden dengan obesitas memiliki risiko 2 kali gangguan siklus menstruasi (oligomenorrhea) dari reponden dengan status gizi normal. ${ }^{24}$ Oligomenorrhea disebabkan oleh jumlah estrogen yang meningkat dalam darah akibat meningkatnya jumlah lemak tubuh. Kadar estrogen yang tinggi akan berpengaruh negatif terhadap sekresi GnRh. ${ }^{22}$ Kekurangan maupun kelebihan gizi akan berdampak pada penurunan fungsi hipotalamus yang tidak memberikan rangsangan kepada hipofisa anterior untuk menghasilkan FSH (Follicle Stimulating Hormone) dan LH (Luteinizing Hormone). ${ }^{25}$ Sejalan dengan hasil penelitian lain yang menunjukkan bahwa ada hubungan antara body mass indexs dengan siklus menstruasi. ${ }^{22}$ Namun hal ini bertentangan dengan hasil penelitian ini. Hasil uji Rank Spearman menunjukkan bahwa tidak ada hubungan yang signifikan antara status gizi dengan siklus menstruasi remaja vegetarian. Hal ini disebabkan oleh komitmen responden dalam menjalankan diet yang berpengaruh terhadap berat badan responden. Penurunan berat badan secara besar besaran dapat menyebabkan aktifitas gonadotropin dalam mensekresi LH dan FSH menurun. Hal ini berdampak buruk pada siklus menstruasi. ${ }^{26}$

\section{SIMPULAN}

Pemenuhan asupan zat gizi protein, zat besi dan vitamin $\mathrm{C}$ memiliki hubungan yang bermakna dengan siklus menstruasi remaja vegetarian lacto ovo. Tidak ada hubungan asupan vitamin B12 dan status gizi dengan siklus menstruasi remaja vegetarian.
Remaja vegetarian lacto ovo diharapkan untuk memperhatikan asupan makan untuk memenuhi kebutuhan zat gizi baik untuk mensuplai aktifitas hormon pada proses menstruasi maupun untuk proses fisiologis tubuh lainnya. Asupan makan yang memadai dapat mempertahankan status gizi yang normal.

\section{DAFTAR PUSTAKA}

1. Kementerian Kesehatan RI. Situasi kesehatan reproduksi remaja. Jakarta : Kementerian Kesehatan RI; 2014.

2. Santrock, John W. Perkembangan anak edisi 7 Vol.2 Jakarta: Erlangga ; 2011.

3. Duo Li. Effect vegetarian diet on noncommunicable disease. Journal of the Science of Food and Agriculture. 2014; 94: 169 -173.

4. Rizzo, Nico S. et al. Nutrient profiles of vegetarian and nonvegetarian dietary patterns. Journal of the Academy of Nutrition and Dietetics. 2013; 113(12): 1610-1619.

5. McEvoy, C., Temple, N., \& Woodside, J. Vegetarian diets, low-meat diets and health: A review. Public Health Nutrition. 2012; 15(12): 2287-2294.

6. Nugroho, T. Obsgyn: Obstetri dan ginekologi. Yogyakarta: Nuha Medika ; 2012.110-112.

7. Indonesian Vegetarian Society. Komunitas Vegetarian. Jakarta ; 2017.

8. Gallagher ML. The nutrients and their metabolism. In : Mahan LK, EscottStump S. Krause's food, nutrition, and diet therapy. 12th edition. Philadelphia: Saunders; 2008.

9. Grober, U. Mikronutrien penyelarasan metabolik, pencegahan, dan terapi. Jakarta: EGC; 2013. 237268.

10. Sheela J, Sunita G, Savita S, Sulbha J. Association of body mass index with menstrual cycle irregularities in women between $16-40$ year age. PJMS. 2014; 4(1): 59-61.

11. Dars S, Sayed K, Yousufzai Z. Relationship of menstrual irregularities to BMI and nutritional status in adolescent girls. Pak J Med Sci. 2014; 30(1): 140-4.

12. Laupau Buchari. Metode Penelitian kesehatan: metode ilmiah penulisan skripsi, tesis dan disertasi edisi 2. Jakarta : IKAPI ; 2013. 36-39.

13. Adriani, Wirjatmadi. Peranan gizi dalam siklus kehidupan. Jakarta : Kencana; 2012. 25-28.

14. Gandy, W.Joan., Madden, A., Holdsworth, M. Gizi dan dietetika edisi 2. Jakarta: EGC; 2014. 352-353.

15. Sarwono WS. Psikologi remaja. Jakarta: PT. Raja Grafindo Persada; 2012. 52-54. 
16. McCance, Kathryn L., Sue E. Huether, Valentina L. Brashes, Neal S. Rote. Pathophysiology: the biologic basis for disease in adults and children 6th ed. Philadelphia : Mosby Elsevier; 2010.

17. Davis JM, Segars JH. Menstruation and menstrual disorders: anovulation. Glob Libr Women's Med.2009 (diunduh pada 24 Juli 2017). Dapat diakses dalam https://www.glowm.com/section_view/heading/29 5

18. Frank C.tamar, Kim 1 Ginah, Krzemien A,Van Vulgt DA. Effect of menstrual cycle phase on corticolimbic brain activation by visual food cues. Brain research 1363 Elsevier; 2010. 81-92.

19. Cheikh, Al-hourani, Lightwoler. Energy and nutrient intakes during different phases of the menstrual cycle in females in the United Arab Emirates. J Ann Nutr Metab. 2009; 54:124-8.

20. Chandra S, Gupta N, Patel KS. Study of iron status indicators in different phases of menstrual cycle in first year medical college females. International Journal of Research in Medical Sciences; 2017. 5: 46-49.
21. Mary J, Rvlaid T.The effect of gynecologic age, body mass index and psychosocial environment on menstrual regularity among teenaged females. Acta Obstet Gynecol Scand. 2005; 84(7): 645-9.

22. Anggraini L. Status gizi vegetarian pada komunitas vegetarian di yogyakarta (kajian pada lacto-ovo vegetarian dan vegan terhadap status imt, hemoglobin, feritin, dan protein) [Tesis].Yogyakarta: UGM; 2015.

23. Wei S, Schdmidt MD, Dwyer T, Norman RJ, Venn AJ. Obesity and menstrual irregularity: associations with SHBG, testosterone and insulin. Obesity. 2009; 17(5): 1070-6.

24. Paath EF. Gizi dalam kesehatan reproduksi. Jakarta: EGC; 2005.

25. Chavarro JE, Rich-Edwards JW, Rosner BA, Willett WC. Diet and lifestyle in the prevention of ovulatory disorder infertility. Obstet Gynecol. 2007; 110(5): 1050-8.

26. Łagowska, K., Kapczuk, K., Friebe, Z., Bajerska, J. Effects of dietary intervention in young female athletes with menstrual disorders. J Int Soc Sports Nutr. 2014; 11: 21. 